\title{
Korelasi antara Kadar Eosinofil Sekret Hidung dan Darah Tepi pada Anak dengan Rinitis Alergika
}

\author{
Enny Karyani, Wistiani \\ Departemen Ilmu Kesehatan Anak Fakultas Kedokteran Universitas Diponegoro/ RSUP Dr. Kariadi, Semarang
}

\begin{abstract}
Latar belakang. Pada pasien rinitis alergika dapat ditemukan eosinofil di sirkulasi darah maupun pada sekret hidung. Belum diketahui apakah terdapat hubungan dua hal tersebut pada rinitis alergika

Tujuan. Membuktikan adanya korelasi antara eosinofil sekret hidung dan eosinofil darah tepi pada anak dengan rinitis alergika. Metode. Rancangan penelitian cross sectional dengan subyek penderita rinitis alergika anak pada poliklinik RSUP dr. Kariadi dan RSUD Kota Semarang yang didiagnosis sesuai dengan kriteria ARIA 2008. Pengambilan sampel dengan cara consecutive sampling. Dilakukan pengukuran kadar eosinofil sekret hidung dan eosinofil darah tepi. Kadar eosinofil diinterpretasikan dalam bentuk persentase. Kadar eosinofil dianalisis menggunakan uji korelasi Spermann untuk menentukan adanya korelasi antara kadar eosinofil pada sekret hidung dan darah tepi pada anak dengan rinitis alergika.

Hasil. Didapatkan 34 anak rinitis alergika. Median kadar eosinofil sekret hidung 1,0 (0-5,0)\%, kadar eosinofil darah tepi 5,0 $(4-14,5) \%$. Terdapat korelasi bermakna antara kadar eosinofil sekret hidung dan eosinofil darah tepi pada penderita rinitis alergika dengan arah korelasi positif dan dengan kekuatan korelasi kuat. ( $\mathrm{p}=0,0001, \mathrm{r}=0,871$ ).

Kesimpulan. Terdapat hubungan yang kuat antara kadar eosinofil sekret hidung dan darah tepi pada anak dengan rinitis alergika. Sari Pediatri 2015;17(5):355-60.
\end{abstract}

Kata kunci: rinitis alergika anak, eosinofil sekret hidung, eosinofil darah tepi

\section{Correlation between Nasal Eosinophil Levels and from Peripheral Blood Smear in Children with Allergic Rhinitis}

Enny Karyani, Wistiani

Background. There is an increase eosinophil levels among patients with allergic rhinitis, in the blood circulation as well as in nasal secretions. It has not been established whether there is a relationship between these two eosinophil levels in allergic rhinitis patients.

Objective. To prove the existence of a correlation between eosinophils in nasal secretions and peripheral blood eosinophils in children with allergic rhinitis.

Method. Cross sectional study design with the subjects of children with allergic rhinitis patients, visiting Dr. Kariadi Hospital clinic in Semarang, that were diagnosed according to the criteria of the 2008 ARIA sampling by means of consecutive sampling. Each participating child had levels of eosinophils nasal secretions and peripheral blood eosinophils measured. Levels of eosinophils were interpreted as a percentage. Eosinophil levels were analyzed using correlation Spearmann to determine the correlation between the levels of eosinophils in the nasal secretions and peripheral blood in children with allergic rhinitis.

Results. Thirty four children with allergic rhinitis were enrolled into the study. Median levels of eosinophils from nasal secretions was $1,0(0-5,0) \%$, and from peripheral blood eosinophil levels were 5.0 (4-14,5)\%. There is a significant correlation between the levels of eosinophils nasal secretions and peripheral blood eosinophils in patients with allergic rhinitis and the direction of the positive correlation with a strong level correlation. $(\mathrm{p}=0,0001, \mathrm{r}=0,871)$.

Conclusions. There is a strong relationship between the levels of eosinophils nasal secretions and in peripheral blood in children with allergic rhinitis. Sari Pediatri 2015;17(5):355-60.

Keywords: children allergic rhinitis, nasal secretions eosinophils, peripheral blood eosinophils

Alamat korespondensi: Dr. Enny Karyani, Sp.A. RSUD Dr. Doris Sylvanus Palangka Raya. Jl. Tambun Bungai No. 4, Palangka Raya,

KALTENG. E-mail: ennyk2@gmail.com 
Enny Karyani dkk: Korelasi antara kadar eosinofil sekret hidung dan darah tepi pada rinitis alergika

$\mathrm{R}$ initis alergika merupakan salah satu penyakit alergi yang sering dijumpai di masyarakat. Rinitis alergika merupakan suatu inflamasi pada mukosa rongga hidung Penyebab rinitis alergika adalah reaksi hipersensitivitas tipe I yang di picu oleh aeroalergen. Di setiap negara, prevalensi penderita rinitis alergika bervariasi karena perbedaan geografi dan potensi aeroalergen. ${ }^{1}$ Gejala rinitis alergi diperberat bila terdapat riwayat alergi pada keluarga (faktor genetik), tinggal pada suhu udara berkisar 23$25^{\circ} \mathrm{C}$, faktor pekerjaan atau lingkungan, paparan asap rokok, pabrik di sekitar rumah, umur, jenis kelamin, dan riwayat alergi sebelumnya. ${ }^{2}$ Pada anak di Eropa Barat, prevalensi rinitis alergika dan remaja sebesar 20\%, sedangkan di Amerika Utara dan Korea sekitar 10\%$20 \%$, Jepang $10 \%$, Thailand 20\%, dan New Zealand $25 \% .^{3}$ Di Indonesia, angka kejadian rinitis alergi yang pasti belum diketahui karena sampai saat ini belum pernah dilakukan penelitian multisenter. Penelitian Nency $^{4}$ di Semarang dengan kuesioner ISAAC pada anak sekolah dasar usia 6-7 tahun didapatkan jumlah kasus alergi berturut-turut meliputi asma $8,1 \%$, rinitis alergika $11,5 \%$, dan eksim 8,2\%. Suprihati ${ }^{5}$ di Semarang tahun 2001-2002 didapatkan prevalensi rinitis alergika pada anak sekolah usia 13-14 tahun 18\%.

Apabila tubuh kembali terpapar dengan alergen yang sama maka IgE yang melekat pada permukaan sel basofil dan sel mast, akan bereaksi dengan alergen tersebut. Sel mast mengalami degranulasi diikuti pelepasan mediator, seperti histamin, bradikinin, eosinophil chemotactic of anaphylaxis (ECF-A), slow reacting factor of anaphylaxis (SRS-A). Histamin dan ECF-A juga akan menyebabkan pelepasan eosinofil dari sumsum tulang ke sirkulasi darah. ${ }^{6,7}$ Selain dalam sirkulasi darah, eosinofil akan menuju ke jaringan yaitu pada mukosa hidung. Terdapatnya eosinofil di mukosa dan sekret hidung merupakan tanda respon nasal pada rinitis alergika. Peningkatan jumlah eosinofil dalam apusan sekret hidung merupakan indikator yang lebih sensitif dibandingkan eosinofilia darah tepi dan dapat membedakan rinitis alergi dari rinitis lainnya. ${ }^{8,9,10}$

Eosinofil akan mengalami peningkatan pada kasus alergi, baik di darah tepi maupun sekret hidung. ${ }^{8}$ Namun, secara pasti belum diketahui apakah terdapat hubungan kedua hal tersebut pada anak dengan rinitis alergika.

Berdasarkan hal tersebut, peneliti akan membuktikan korelasi antara eosinofil sekret hidung dan darah tepi pada anak berusia 6 bulan - 14 tahun dengan rinitis alergika.

\section{Metode}

Penelitian cross sectional untuk menganalisis korelasi antara kadar eosinofil sekret hidung dan darah tepi pada anak dengan rinitis alergika. Penelitian dilakukan di Poliklinik Anak, Poliklinik Telinga Hidung Tenggorokan dan Alergi RSUP dr. Kariadi Semarang dan RSUD Kota Semarang pada periode September 2013 - September 2014.

Populasi target adalah adalah pasien rinitis alergika usia 6 bulan -14 tahun, dan populasi terjangkau adalah usia 6 bulan-14 tahun. Sampel adalah pasien rinitis alergika usia 6 bulan -14 tahun yang berobat jalan di poliklinik anak, poliklinik telinga hidung tenggorokan dan alergi RSUP dr. Kariadi Semarang dan RSUD Kota Semarang, serta memenuhi kriteria inklusi dan orangtua menyetujui ikut dalam penelitian. Kriteria eksklusi adalah sedang dalam pengobatan antihistamin maupun kortikosteroid dalam 1 minggu terakhir dan menderita kecacingan. Pengambilan sampel dengan cara consecutive sampling sampai besar sampel terpenuhi. Dilakukan pemeriksaan laboratorium kadar eosinofil darah, kadar eosinofil sekret hidung, dan fases rutin (untuk menyingkirkan kecacingan). Dilakukan pengambilan darah $1 \mathrm{kali}(3 \mathrm{cc})$ saat pertama kali diagnosis ditegakkan. Pengambilan darah dilakukan oleh tenaga medis/paramedis terlatih dan berpengalaman. Dilakukan pengambilan sekret hidung di bagian medial konka inferior dengan menggunakan ringhaak, diputar 2-3 kali. Sekret hidung tersebut dioleskan pada gelas objek secara merata dengan cara memutar, keringkan, kemudian dikirim ke laboratorium untuk dicat dengan pewarnaan giemsa.

Dilakukan analisis deskriptif dan uji hipotesis. Pada analisis deskriptif, data yang berskala kategorial, seperti jenis kelamin, pendidikan orang tua, pekerjaan orang tua, dan sebagainya dinyatakan sebagai distribusi frekuensi dan persentase. Sebelum uji korelasi antara kadar eosinofil sekret hidung dan eosinofil darah tepi, dilakukan uji normalitas data dengan uji Kolmogorov Smirnov. Didapatkan distribusi data tidak normal $(\mathrm{p}<0,05)$ maka digunakan uji korelasi Spearmann. Penelitian telah mendapatkan lolos kaji etik dari Komisi Etik Penelitian FK UNDIP dengan no. 256/ EC/FK-RSDK/2014. 


\section{Hasil}

Selama periode penelitian didapatkan 34 anak dengan rinitis alergika yang sesuai dengan kriteria penelitian.

Tabel 1. Karakteristik subyek penelitian $(\mathrm{n}=34)$

\begin{tabular}{|c|c|}
\hline Variabel & $\mathrm{n}(\%)$ \\
\hline \multicolumn{2}{|l|}{ Jenis kelamin } \\
\hline Laki - laki & $21(61,8)$ \\
\hline Perempuan & $13(38,2)$ \\
\hline \multicolumn{2}{|l|}{ Pendidikan Ibu } \\
\hline SD & $1(2,9)$ \\
\hline SMP & $13(38,2)$ \\
\hline SMA & $17(50)$ \\
\hline D3 & $2(5,9)$ \\
\hline Perguruan tinggi & $1(2,9)$ \\
\hline \multicolumn{2}{|l|}{ Pendidikan ayah } \\
\hline SD & $2(5,9)$ \\
\hline SMP & $7(20,6)$ \\
\hline SMA & $21(61,8)$ \\
\hline D3 & $3(8,8)$ \\
\hline Perguruan tinggi & $1(2,9)$ \\
\hline \multicolumn{2}{|c|}{ Pekerjaan orang tua } \\
\hline Wiraswasta & $19(55,9)$ \\
\hline PNS/ABRI & $4(11,8)$ \\
\hline Pegawai swasta & $8(23,5)$ \\
\hline Lainnya & $3(8,8)$ \\
\hline \multicolumn{2}{|l|}{ Asma bronkial } \\
\hline Ya & $2(5,9)$ \\
\hline Tidak & $32(94,1)$ \\
\hline \multicolumn{2}{|l|}{ Dermatitis kontak } \\
\hline Ya & $1(2,9 \%)$ \\
\hline Tidak & $33(97,1 \%)$ \\
\hline \multicolumn{2}{|c|}{ Riwayat merokok dalam satu rumah } \\
\hline Ya & $19(55,8)$ \\
\hline Tidak & $15(44,1)$ \\
\hline \multicolumn{2}{|c|}{ Pabrik di sekitar rumah } \\
\hline Ya & $2(5,9)$ \\
\hline Tidak & $32(94,1)$ \\
\hline \multicolumn{2}{|c|}{ Riwayat alergi pada keluarga } \\
\hline $\mathrm{Ya}$ & $14(41,2)$ \\
\hline Tidak & $20(58,8)$ \\
\hline \multicolumn{2}{|c|}{ Paparan debu rumah } \\
\hline Ya & $12(35,3)$ \\
\hline Tidak & $22(64,7)$ \\
\hline
\end{tabular}

Karakteristik subyek penelitian tertera pada Tabel 1 . Dari 34 anak didapatkan median usia anak 5 tahun 6 bulan dengan usia termuda adalah 6 bulan dan tertua adalah 14 tahun.

Digunakan uji korelasi Spearmann untuk analisis korelasi antara kadar eosinofil sekret hidung dan eosinofil darah tepi, meskipun telah dilakukan transformasi data, karena sebaran data yang tidak normal. Terdapat korelasi bermakna antara kadar eosinofil sekret hidung dan kadar eosinofil darah tepi pada anak dengan rinitis alergika dengan arah korelasi positif dan dengan kekuatan korelasi kuat $(\mathrm{p}=0,0001, \mathrm{r}=0,871)$.

\section{Pembahasan}

Kami menemukan bahwa proporsi laki-laki $(61,8 \%)$ lebih banyak daripada perempuan (38,2\%). Pada anak laki-laki, kejadian alergi yang tinggi pernah diteliti dan dikaitkan dengan kenaikan kadar Ig E. Anak laki-laki mempunyai kadar Ig E lebih tinggi daripada perempuan dan pada anak dengan riwayat atopi didapatkan kadar Ig E > 0,9 U/L. ${ }^{11}$ Nency ${ }^{4}$ melaporkan bahwa jenis kelamin laki-laki berpengaruh terhadap kejadian rinitis alergika. Usia pasien penelitian kami adalah nilai median 5 tahun 5 bulan. Hal tersebut sesuai dengan penelitian $\mathrm{Akib}^{12}$ yang melaporkan bahwa insiden tertinggi rinitis alergi pada kelompok umur 6-10 tahun. Di Jepang, Masuda $\mathrm{dkk}^{13}$ melaporkan bahwa $9 \%$ anak-anak dengan rinitis alergika dengan manifestasi gejala klinis dimulai pada tahun pertama kehidupan dan $22,5 \%$ pada usia 2 tahun. Rerata usia pertama kali terdiagnosis oleh dokter pada 3,5 $\pm 1,7$ tahun. Di Semarang tahun 2001-2002, Suprihati ${ }^{5}$ melaporkan $18 \%$ prevalensi gejala rinitis alergika pada anak sekolah usia 13-14 tahun.

Pendidikan dan pekerjaan orang tua merupakan karakteristik yang dinilai pada penelitian kami. Pendidikan ayah dan ibu terbanyak adalah SMA dengan jenis pekerjaan terbanyak adalah wiraswasta $(55,9 \%)$. Chamara $\mathrm{dkk}^{14}$ melaporkan kejadian alergi pada anak lebih sering terjadi dan tergantung pada tingkat pendidikan orang tua mereka yang meliputi pendidikan ibu dan pendidikan ayah.

Tabel 2. Korelasi kadar eosinofil sekret hidung terhadap kadar eosinofil darah tepi

\begin{tabular}{lccc}
\hline Variabel & Median (minimum-maksimum) & $\mathrm{p}$ & $\mathrm{r}$ \\
\hline Kadar eosinofil darah tepi & $5,0(4-14,5) \%$ & \multirow{2}{*}{0,0001} & \multirow{2}{*}{0,871} \\
Kadar oesinofil sekret hidung & $1,0(0-5,0) \%$ & & \\
\hline
\end{tabular}


Kami menemukan bahwa selain menderita rinitis alergika, terdapat 2 orang anak yang juga menderita asma bronkial dan 1 anak dengan dermatitis kontak. Terdapat 14 orang anak dengan riwayat alergi dalam keluarga. Faktor genetik berperan terjadinya penyakit atopi. Apabila didapatkan salah satu dari orang tua atopi maka kemungkinan $30 \%$ anaknya menderita atopi dan apabila kedua orang tua menderita atopi maka 50\% kemungkinan anaknya menderita atopi. ${ }^{15}$ Manifestasi penyakit atopi seringkali ditandai dengan adanya penyakit atopi, seperti rinitis alergi, asma, dan dermatitis eksema. Pada penderita atopi ditunjukkan gambaran polimorfik pada kromosom 5 q sehingga mudah tersensitisasi. ${ }^{16}$ Di Semarang, pada anak usia 6-7 tahun, Nency ${ }^{4}$ melaporkan bahwa ibu dengan riwayat alergi tidak berhubungan dengan timbulnya rinitis alergika dan ayah dengan riwayat alergi tidak berhubungan dengan timbulnya rinitis alergika.

Dua orang anak bertempat tinggal berdekatan dengan pabrik tekstil. Bahan iritan saluran nafas, seperti sulfur dioksida, nitrogen oksida, dan partikel hasil pembakaran mesin diesel di pabrik menyebabkan peningkatan Ig E dengan berbagai mekanisme dan inflamasi lokal pada saluran pernafasan. Hal tersebut mengakibatkan terjadi peningkatan kontak antara jaringan dengan alergen sehingga timbul respon imun. ${ }^{17}$ Pada seorang perokok akan terjadi peningkatan kadar cadmium di dalam darah yang menyebabkan peningkatan Ig E, dengan manifestasi alergi seperti pada rinitis alergika dan asma. ${ }^{18}$

Didapatkan 19 anak dengan riwayat keluarga merokok dalam satu rumah. Penelitian Pujo ${ }^{19}$ melaporkan bahwa asap rokok tidak berpengaruh terhadap rinitis alergika. Paparan debu rumah didapatkan pada 12 orang anak. Soewito melaporkan bahwa alergen terbanyak penderita rinitis alergika adalah tungau debu rumah dan kecoa. ${ }^{20}$ Tungau debu rumah merupakan alergen utama yang terdapat pada debu rumah dan berkembang di tempat tidur, bantal, karpet, perabot rumah tangga dengan suhu $25^{\circ} \mathrm{C}$ $30^{\circ} \mathrm{C}$ dan kelembaban tinggi $>60 \%$. Kota Semarang memiliki suhu rata-rata $27,5^{\circ} \mathrm{C}$ dan kelembaban udara rata-rata $75 \% .{ }^{21}$

Tigapuluh empat anak dengan rinitis alergika yang mempunyai median kadar eosinofil darah tepi 5\% dengan nilai terendah $4 \%$ dan nilai tertinggi $14,5 \%$. Sementara itu, nilai median eosinofil sekret hidung $1 \%$ dengan nilai terendah $0 \%$ dan nilai tertinggi $5 \%$. Zhu dkk ${ }^{22}$ melaporkan bahwa terjadi peningkatan jumlah eosinofil darah tepi pada anak dengan rinitis alergi usia 3-17 tahun. Terdapat korelasi antara kadar serum eosinophil cationic protein (ECP) dan jumlah eosinofil darah tepi pada penderita rinitis alergika. Hasil tersebut sesuai dengan teori yang menyatakan bahwa sel eosinofil merupakan sel yang cocok untuk keadaan alergi yang kemunculannya dalam sirkulasi cenderung karena aktivitas dari sel mast pada reaksi hipersensitivitas. ${ }^{23}$ Untuk kasus rinitis alergika ini, reaksi hipersensitivitas yang terjadi adalah reaksi tipe I yang sangat dipengaruhi oleh immunoglobulin E (IgE). Antibodi ini melekat pada sel mast dan apabila IgE ini kontak dengan alergen yang sama akan terjadi degranulasi dari sel mastosit dan keluarlah granula-granula, seperti histamine, serotonin, eosinophilchemotactic factor (ECF-A), slow reactivating factor of anaphylaxis (SRS-A) ke dalam sirkulasi. Mekanisme inilah yang mendasari ditemukannya eosinofil pada keadaan alergi. ${ }^{24,25}$ Di Shiraz, Miri $\mathrm{dkk}^{26}$ melaporkan bahwa terdapat peningkatan kadar eosinofil sekret hidung anak usia 11-15 tahun dengan rinitis alergika. Keberadaan eosinofil di mukosa hidung ini terjadi akibat pergerakan eosinofil yang dilepaskan ke dalam sirkulasi pada reaksi hipersensitivitas menuju ke organ sasaran. Migrasi eosinofil dari pembuluh darah ke mukosa sinus dan hidung adalah migrasi transendotel dan ditentukan oleh 3 faktor, yaitu eosinophil priming cytokines (IL-3, IL-5 dan GM-CSF), chemoatractan (Leukotrien B4, platelet activating factor), sitokin di mukosa hidung, dan CC-chemokine (eotaxin, eotaxin-2, RANTES). ${ }^{27}$ Organ sasaran yang terlibat pada kasus rinitis alergika adalah mukosa hidung sehingga eosinofil dalam mukosa hidung sering sebagai sel yang dominan dalam kasus rinitis alergika.

Terdapat hubungan antara kadar eosinofil darah tepi dan kadar eosinofil di sekret hidung. Chen $\mathrm{dkk}^{28}$ melaporkan bahwa terdapat korelasi antara kadar eosinofil darah tepi, eosinophil cationic protein (ECP), dan Ig E terhadap keparahan rinitis alergika pada anak. Artika $\mathrm{dkk}^{29}$ melaporkan terdapat hubungan linear positif antara jumlah eosinofil darah tepi dengan jumlah eosinofil sekret hidung, antara eosinofil darah tepi dengan $\operatorname{IgE}$ total pada penderita rinitis alergika dewasa.

Faktor perancu pada penelitian adalah asma bronkial, dermatitis kontak/eksema, paparan asap rokok, riwayat alergi dalam keluarga, dan pabrik sekitar rumah. Dilakukan uji korelasi setelah menyingkirkan 
Enny Karyani dkk: Korelasi antara kadar eosinofil sekret hidung dan darah tepi pada rinitis alergika

faktor perancu, didapatkan korelasi yang bermakna antara kadar eosinofil sekret hidung dan darah tepi pada anak dengan rinitis alergika. Eosinofil mukosa hidung berkorelasi positif dengan tingkat gejala rinitis alergika sehingga waktu pengambilan yang tidak tepat sangat memengaruhi hasil. Pada pasien yang tidak kooperatif sering dialami kesulitan dalam pengambilan sampel sekret hidung.

Keterbatasan pada penelitian kami adalah kadar eosinofil yang hanya dapat diinterpretasikan dalam bentuk persentase, tidak dapat dinilai jumlah absolut.

\section{Kesimpulan}

Terdapat hubungan yang kuat antara kadar eosinofil darah tepi dan kadar eosinofil sekret hidung pada anak dengan rinitis alergika.

\section{Daftar pustaka}

1. Bousquet J, Khaltaev K, Cruz. A, Denburg, Fokkens W, Togias A, dkk. Allergic Rhinitis and its Impact on Asthma (ARIA). Allergy 2008;63:8-160.

2. Tan W. Epidemiology of allergic rhinitis and its associated risk factor in Singapore. Int. J. Epidemiol 1994;23:553-8.

3. Celikel S, Isik SR, Demir AU, Karakaya G, Klyoncu AF. Risk factors for asthma and other allergic disease in seasonal rhinitis. J Asthma 2008;45:710-4.

4. Nency YM. Prevalensi dan faktor risiko alergi pada anak usia 6-7 tahun di Semarang, tesis. Semarang: Fakultas Kedokteran Universitas Diponegoro, 2005.

5. Suprihati. The prevalence of allergic rhinitis and its relation to some risk factors among 13-14 years old students in Semarang. Indonesian J Otorhinolaryngology, Head and Neck Surg 2005;35:64-70.

6. Moqbel R, Becker AB. The human eosinophil. Dalam: Clinical hematology, penyunting. Philadelphia: William and William A Waverly Company Baltimore; 1999.h.36.

7. Orathai J, Pakit V. Nasal Cytology in The Diagnosis of Alergic Rhinitis In Children. Annlas of Allergic Ashma and Immunology 1998;2:165-9.

8. Uller L. Early phase resolution of mucosal eosinophilic inflamation in allergic rhinitis. Respiratory Res 2010;11:54.
9. Atkins D, Leung DYM. Diagnosis of allergic disease. Dalam: Behrman RE, Kliegman RM, Jenson HB, penyunting. Nelson textbook of pediatrics. Edisi ke-17. Philadelphia: Saunders; 2004.h.747-51.

10. Leung DYM. Diagnosis and treatment of allergic disease. Dalam: Leung DYM, Sampson HA, Geha RS, Szefler SJ, penyunting. Pediatric allergy: principles and practice. Edisi ke-1. Missouri;2003.h.233-51.

11. ETAC Science. Evidence of rising prevalence of allergic diseases and possible contributing factors. ETAC; 1996.

12. Akib AAP. Pengobatan dini anak atopi. Dalam: Harsoyo N, Hapsari, penyunting. Penatalaksanaan alergi dan infeksi pada bayi dan anak masa kini. Semarang: BP UNDIP; 2002.h.73-85.

13. Masuda S, Fujisawa T, Katsumata H, Atsuta J, Iguchi. High prevalence and young onset of allergic rhinitis in children with bronchial asthma. Pediatr Allergy Immunol 2008;19:517-22.

14. Chamara RP, Wronka I, Muc M. Prevalence and correlates of allergic diseases among children. J Physiol and Pharmacol 2008;59:549-56.

15. Naclerio R, Solomon W. Rhinitis and inhalant allergens. JAMA 1997;278:1842-8.

16. Rona RJ, Tauleria ED, Chinn S. Family size, atopi disorders in parents, asthma in children, and ethnicity. J Allergy Clin Immunol 1997;99:454-60.

17. Burmester GR, Pezutto A. Respiratory diseases. Dalam: Color atlas of immunology. Stuttgart: Georg Thieme Verlag; 2003.h.214-5.

18. Morkjaroenpong V, Rand CS, Butz AM, Huss K, Eggleston P, Maveaux FJ, dkk. Environmental tobacco smoke exposure and nocturnal symtoms among inner city children with asthma. J Allergy Clin Immunol 2002;1:147-53.

19. Widodo P. Hubungan antara rinitis alergi dengan faktorfaktor risiko yang mempengaruhi pada siswa SLTP kota Semarang usia 13-14 tahun dengan mempergunakan kuesioner international study of asthma and allergies in childhood. Semarang: Bagian THT-BKL Fakultas Kedokteran Universitas Diponegoro, 2004.

20. Soewito MY,Azis M. Gambaran umum penderita suspek rinitis alergi yang dilakukan tes cukit kulit alergen inhalan di Poli Alergi Imunologi RSWS tahun 2005-2006. Dalam: Kumpulan Abstrak KONAS Perhimpunan Dokter Spesialis THT-KL Indonesia. Surabaya; 2007.h.13.

21. Paramita OD. Association between asthma, allergic rhinitis, atopic dermatitis and spesific age in 6-7 years old children (tesis). 
Semarang: Fakultas Kedokteran Universitas Diponegoro, 2011.

22. Zhu XJ, Lu MP, Chen RX. Correlation of serum eosinophil cationic protein with the severity of allergic rhinitis in childhood. Article in Chinese 2012;47:62832.

23. Martin AS, Steiningh CAL, Koephe JA. The Eosinophil. Dalam: Clinical hematology principal procedures correlation. Anne Stiene Martin, penyunting. Philadelphia-New York: Lippincop; 1998.h.132.

24. Rothenberg ME, Epstein FH. Eosinophilia. New Engl Med 1998;28:1952-8.

25. Kramer MF, Ostertag P, Pfrogner E, Rasp G. Nasal interleukin-5, immunoglobulin $\mathrm{E}$, eosinophilic cationic protein, and soluble intercellular adhesion molecule- 1 in chronic sinusitis, allergic rhinitis, and nasal polyposis.
Laryngoscope 2000;110:1056-62.

26. Miri S, Farid R, Akbari H, Amin R. Prevalence of allergic rhinitis and nasal smear eosinophilia in 11 to 15 yr old children in Shiraz. Pediatr Allergy Immunol 2006;17:519-23.

27. Poznanovic SA, Kingdom T. Total IgE levels and peripheral eosinophilia. Arch Otol Head Neck Surg 2007;133:701-15.

28. Chen ST, Sun HL. Correlation of immunoglobulin E, eosinophil cationic protein, and eosinophil count with the severity of childhood perennial allergic rhinitis. J Microbiol Immunol Infect 2006;39:212-8.

29. Artika D. The Correlation between eosinophil cells in the nasal secret and in peripheral blood in acute asthma cases, tesis. Denpasar: Fakultas Kedokteran Universitas Udayana, 2000. 